\title{
Arabuluculuğun getirileri: Çatışmaya dönüşümsel bir yaklaşım
}

\author{
Çiğdem DEMİR ÇELEBi் $\left.{ }^{*}\right]$
}

Kitabın Orijinal Adı : The Promise of Mediation: The Transformative Approach to Conflict.

Kitabın Yazarı

Yayınevi

Basım Yılı

Sayfa Sayısı

ISBN
: Robert A. Baruch Bush, Joseph P. Folger

: Jossey- Bass, San Francisco

: 2005

: 288

: 0-7879-7483-8

Arabuluculuk, iki ya da daha fazla birey/kurum arasında yaşanan çatışmaların giderilmesinde, karar uygulama yetkisi olmayan üçüncü kişilerin yardımcı olmaları sürecidir. Son zamanlarda arabuluculuk üzerine pek çok çalışma yapıldığı, arabuluculuk uygulamalarının dünyada ve ülkemizde giderek yaygınlaştı̆̆1 görülmektedir. Robert A. Baruch Bush ve Joseph P. Folger tarafından kaleme alınmış olan The Promise of Mediation: The Transformative Approach to Conflict adlı kitapta da arabuluculuk sistemine yeni bir bakış kazandırmış olan dönüşümsel arabuluculuk modeli hakkında bilgi sunulmaktadır.

The Promise of Mediation: The Transformative Approach to Conflict, aynı yazarlar tarafindan yazılmış olan The International Association for Conflict Management adlı kitabın devamı niteliğindedir. Kitap, toplam 288 sayfadan ve 7 ana bölümden oluşmaktadır. Arabuluculuk alanına genel bir bakış sunan ilk bölümde, ilerleyen bölümlerde anlatılacak olan dönüşümsel arabuluculuk modelinin daha iyi anlaşılmasına zemin hazırlayacak bilgilere yer verilmekte; arabuluculuğa ilişkin farklı bakışlar sunan modellere değinilmektedir. Kitabın ikinci bölümünde dönüşümsel arabuluculuk modelinin tanıtımına giriş yapılmaktadır. Bölüm içinde dönüşümsel

${ }^{[*}$ Araştırma Görevlisi, Marmara Üniversitesi, Atatürk Eğitim Fakültesi, İstanbul, Türkiye,

e-posta: cigdem.demircelebi@marmara.edu.tr 
arabuluculuk modelinin getirileri, hedefleri ve faydaları üzerinde durularak, modelin kuramsal temeli ile ilgili araştırmalar hakkında bilgi verilmektedir. Kitabın üçüncü bölümünde ise, dönüşümsel arabuluculuk modelinin çeşitli alanlardaki etkileri irdelenmektedir. Modelin hangi alanlarda ne amaçla kullanıldığı ve arabulucuların ne tür çatışmalarda başarılı olduğu konusu bu bölümde yer almaktadır. Kitabın dördüncü ve beşinci bölümünde, dönüşümsel arabuluculuk modelinin yürütülmesinde gerekli olan temel beceriler, materyaller ve yazarın yorumları "Mor Ev" adlı örnek hikâye üzerinden ele alınmaktadır. Altıncı bölümde, dönüşümsel arabuluculuk modeli konusundaki yanlış anlaşılmalara değinilmekte ve bunlara ilişkin sorulara cevaplar sunulmaktadır. Kitabın son ana bölümünde ise çözüm odaklı arabuluculuk modeli yerine dönüşümsel arabuluculuk modelinin tercih edilmesi hususunun nedenleri üzerinde durulmaktadir.

Kitap içinde, dönüşümsel modelin neden kullanılacağına ilişkin bilgi, çözüm odaklı arabuluculuk modelleriyle karşılaştırmalı biçimde verilmektedir. Bu sayede dönüşümsel arabuluculuk modelinin alandaki ne tür eksiklikleri giderdiği ve ne amaçla kullanıldığı daha iyi anlaşılmaktadır. Kitaptan edinilen bilgilere göre, çözüm odaklı arabuluculuk modellerinde daha çok problem üzerinde durulmakta; çatışma sürecinde kişilerarası ilişkilerin önemi göz ardı edilmektedir. Dönüşümsel arabuluculuk modelinde ise değerler ve ilişkinin önemine vurgu yapılarak çatışma bir firsat olarak görülmekte, arabuluculuğun çatışma çözmedeki olumlu yönüne dikkat çekilmektedir. Dönüşümsel arabuluculuk modeli, arabuluculuk uygulamasına esas olan problemi, kişiler arasındaki ilişkiye odaklanarak çözmeyi amaçlamaktadır. Bu modele göre, çatışma çözümü için arabuluculuk hizmeti almaya gelen bireylerin kişilerarası ilişkilerine dokunulmadan çözüme odaklanmak, başka bir problemin su yüzüne çıkmasına neden olmakta; bu bireyler benzer bir sorunla karşılaştıklarında yine arabulucu desteğine ihtiyaç duymaktadırlar. $\mathrm{Bu}$ bakımdan dönüşümsel arabuluculuk modeli sürecinde, bireylerin birbirlerini dinleyip anlamaları ve problemlerine ortak bir çözüm bulmaları amaçlanmaktadır. Böylece bireylerin, yeni bir problemle yüzleştiklerinde bunun üstesinden kolayca geleceklerine inanılmaktadır. Ayrıca çatışmanın çözümüne ilişkin adımın ortak bir şekilde belirlenmesi halinde tarafların bu adımı uygulamakta daha istekli olacaklarına inanılmaktadır.

Arabuluculuk sisteminde arabulucunun özel bir rolü vardır. Kitap içinde verilen örneklerle arabulucunun arabuluculuk sistemi içindeki yeri ve rolü açık bir biçimde ortaya konmakta ve böylece dönüşümsel modeli diğer arabuluculuk modellerinden ayıran yönler net bir biçimde anlaşılmaktadır. "Mor Ev" örneğinde de görüldügü üzere arabulucu, süreç içinde yönlendirici olmayan bir role sahiptir. Arabuluculuk sürecinde sistemden faydalanan bireyler problem üzerinde konuşmakta, problemi kendi açılarından ele almakta, probleme çözüm önerileri sunmakta, ortak bir karar almakta ve istedikleri zaman da oturumu sonlandirmaktadırlar. Arabulucu, çatışmalarını çözmeye çalışan bireylerin birbirlerini dinlemeleri ve birbirlerinin bakış açıları ile duygularını anlamaları için gerekli koşulları sağlamakla yükümlüdür. Tarafları harekete geçmeleri için cesaretlendirmek ve gerektiği zaman konuşmaları özetleyip çatışmayı yapıcı hale getirmek de arabulucunun görevleri arasındadır. Arabulucu, çatışmanın çözümü için kesinlikle öneride bulunmamakta ve oturumun sonlandırılmasına karar vermemektedir. 
Bu durum, dönüşümsel arabuluculuk modelini çözüm odaklı modellerden ayıran özelliklerden biridir. Çözüm odaklı modellerde arabulucu oldukça aktif, yönlendirici ve sorunlara çözüm önerici bir rol üstlenmektedir. Dönüşümsel arabuluculuk modelinde ise çatışma çözümü hoş bir çıktıdır, ancak hiçbir zaman temel amaç niteliği taşımamaktadır. İnsanların kendi problemlerini çözebileceğine ve arabulucunun da onları destekleyeceğine inanan dönüşümsel arabuluculuk modelinde temel amaç, olumsuz bir yola sürüklenmiş çatışmayı olumlu bir zemine alarak bireylerin birbirlerini dinleyip anlamalarını sağlamaktır.

Kitapta, dönüşümsel arabuluculuk modeli ile arabuluculukta değerler ve kişilerarası ilişkilerin önemine vurgu yapılarak, sadece ilgili soruna ilişkin geçici çözümlerin ötesine geçildiği ve hem ilişkinin gelişimine, hem de olası problemlerin çözümüne katkı sağlandığı belirtilmektedir. Arabuluculuğun ilişkiler üzerine odaklanmasıyla birlikte, kişilerarası iletişimde yaşanan problemlere ilişkin çözümlerin uzun vadeye yayılacağına dair umutlar artmaktadır. Kitabın, arabuluculuk uygulamalarının yaygınlaştırılması ve etkililiklerinin artırılması hususunda yapılacak çalışmalara yeni bir bakış kazandıracağı ve katkı sunacağı düşünülmektedir. 
